\title{
脳卒中片麻痺患者における下肢荷重力と立ち上がり・ 立位保持・歩行能力との関係
}

\author{
Relationship between Lower Limb Loading Force and Standing up, Standing Postural \\ Control and Walking Ability of Hemiplegic Patients
}

$\begin{array}{lllll}\text { 村田 } & \text { 伸1)* } & \text { 大田尾 浩1) } & \text { 有馬 幸史 }{ }^{2)} & \text { 溝上 昭宏2) } \\ \text { 村田 } & \text { 潤3) } & \text { 弓岡 光德1) } & \text { 武田 } \quad \text { 功1) } & \end{array}$

SHIN MURATA ${ }^{1)}$, HIROSHI OTAO ${ }^{1)}$, KoJI ARIMA ${ }^{2)}$, AKIHIRO MIZOKAMI ${ }^{2)}$, JUN MURATA ${ }^{3)}$, MITSUNORI YUMIOKA ${ }^{1)}$, ISAO TAKEDA ${ }^{1)}$,

${ }^{1)}$ Department of Physical Therapy, Faculty of Health Care Science, Himeji Dokkyo University: 7-2-1 Kamiohno, Himeji-city, Hyogo 670-8524, Japan. TEL +81 079-223-2211

*Present address: Faculty of Rehabilitation Sciences, Nishikyushu University: 4490-9 Oshaki, Kanzaki-machi, Kanzaki-city, Saga 842-8585, Japan. TEL +81 952-52-4191

2) Department of Rehabilitation, Kahan Hospital

3) Department of Health Sciences, Graduate School of Biomedical Sciences, Nagasaki University

Rigakuryoho Kagaku 23(2): 235-239, 2008. Submitted Aug. 30, 2007. Accepted Oct. 26, 2007.

\begin{abstract}
In this study we investigated the applicability and limits of using commercially available bathroom scales for measuring lower limb loading force. The subjects were 53 hemiplegic stroke patients. We measured their walking, standing, and standing up abilities, and the maximum value of their lower limb loading force of the right and left legs separately in the sitting position. No significant differences were found in lower limb loading forces among those who could walk outside, those who could walk inside, those who could keep a standing position without using upper limb, and those who could keep a standing position with upper limb. However, when the ability of each action was high the lower leg loading force was significantly strong, suggesting that this method of measuring values of lower limb loading force could be used as an index for judging whether or not each action is possible. Although this method could be used to judge whether or not walking and keeping a standing position were possible, its limitations were also shown and it would be inappropriate to use it as a detailed functional assessment.
\end{abstract}

Key words: hemiplegic patients, lower limb loading force, walking ability

要旨: 本研究は, 市販体重計を用いた下肢荷重力測定法の有用性とその限界について検討した。対象は片麻痺患 者53名で歩行，立位保持，立ち上がり動作能力と，下肢荷重力の最大值を座位で左右別々に測定した。その結果， 屋外歩行可能群と屋内歩行可能群, 立位保持可能群と条件付き可能群における下肢荷重力には有意差が認められ なかったが, その他の各動作では能力が高いほど下肢荷重力が有意に強かった。よって, 本方法による下肢荷重 力の值は, 各動作の可否判定の指標となることが示唆された。ただし, 歩行や立位保持動作に関しては, 動作の 可否判定の指標としては利用できるが，詳細な機能評価には適していない限界が示された。

キーワード：脳卒中片麻痺患者, 下肢荷重力, 歩行能力

1) 姫路獨協大学 医療保健学部理学療法学科：兵庫県姫路市上大野7-2-1 (

*現所属 : 西九州大学 リハビリテーション学部：佐賀県神埼市神埼町尾崎4490-9（テ842-8585） TEL 0952-52-4191

2) 河畔病院 リハビリテーション科 3) 長崎大学大学院 医歯薬学総合研究科保健学専攻

受付日 2007年8月30日受理日 2007年10月26日 


\section{I. 緒 言}

脳卒中片麻痺患者（片麻痺患者）における下肢運動 機能障害の評価は, その機能障害が定型的な回復パター ンを示すことから, Brunnstrom ステージ (Br.ステージ) が本邦では最もよく用いられている1,2)。Br.ステージは 6段階で評価され簡便であるが, 各ステージ内の幅が広 く詳細な下肢機能評価には適さない。道免ら ${ }^{3,4)}$ は, 包 括的評価尺度としてStroke Impairment Assessment Set （SIAS）を開発し下肢機能を詳細に検討しているが, 評 価に時間を要し患者に負担がかかりやすい。

また近年, 各種測定機器 (等速性筋力測定機器や八 ンドヘルドダイナモメーター, 重心動摇計など) によっ て片麻痺患者の下肢機能を定量的に評価し, 歩行能力 との関連や歩行の予後予測に用いた研究5-10)が散見され るようになった。しかし, それら測定機器は高価なも のが多く, 測定できる臨床現場は限られている。

一方, 安価に片麻痺患者の下肢機能を評価する方法 として, 市販体重計を用いた研究がある。本田ら ${ }^{11)}$ は, 立位時の麻痺側荷重率を体重計で測定して, 歩行やバ ランス能力との関連性を報告し，浅野ら ${ }^{12)}$ は，ブリッ ジ動作中の麻痺側荷重率を体重計で測定して, 麻痺の 回復段階の客観的指標となり得る可能性を報告してい る。しかしながら, それらの方法は立位やブリッジ動 作が行えることが条件となるため, 測定できる対象が 限定されてしまう。山崎ら 13 や大森ら ${ }^{14)}$ は, 体重計を 用いて背臥位で下肢機能を測定できる独自の方法を開 発しているが, 測定時の設定が複雑で, 検者も2名を必 要とするため, 臨床的に用いるには問題も多い。

そこで著者らは, 高齢者および片麻痺患者の下肢機 能を簡便かつ定量的に評価する方法として, 市販体重 計を用いた座位での下肢荷重力測定法を考案し, その 測定值の有用性について報告15,16)してきた。この測定 法の利点は場所を選ばず，座位姿勢で簡易に測定でき るためその適応範囲が広く, リハビリテーション専門 職以外でも測定が可能なことである。

介護老人保健施設に入所中の障害高齢者を対象とし た研究15)では，下肢荷重力の良好な再現性（Intraclass correlation coefficient : 0.823）に加え, Barthel Index（BI） 得点および歩行速度との関連性から, 簡易に下肢機能 を評価できる方法としての妥当性が示唆された。さら に, 片麻痺患者を対象とした研究16)では, 下肢荷重力 とBr.ステージ, Functional Independence Measure (FIM) 得 点, 歩行速度との間に有意な正相関が認められた。ま
た, 歩行可能群と不可能群における下肢荷重力の比較 から, 歩行が可能か否かの指標になり得る可能性が示 唆された。

また，下肢荷重力が示す測定值の意義について，下 肢筋力ならびに座位バランス能力との関連性から検討 した結果，下肢荷重力は下肢筋力のみならず，座位バ ランス能力をも密接に反映していることが明らかとなっ た。このことから，下肢荷重力測定は，下肢ならびに 体幹機能を総合的かつ定量的に評価できる簡易機能評

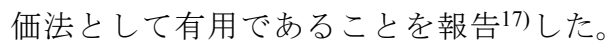

しかしながら，この下肢荷重力測定法が歩行を中心 とした立位動作能力をどの程度反映する評価基準とな り得るかについての検討は行われていない。

そこで本研究は，片麻痺患者を対象に立ち上がり， 立位保持, 歩行の各動作について能力別に下肢荷重力 を比較し，下肢荷重力測定法の有用性とその限界につ いて検討した。

\section{II. 対象と方法}

1. 対象

対象は, 某通所リハビリテーション施設に通所して いる片麻痺患者のうち, 重度の認知症と失語症が認め られない53名（男性25名，女性28名）を対象とした。対 象者の平均年齢は73.5 28.8 歳であり, 疾患名は脳梗塞 が39名と多く, 発症からの期間は平均52.3 月（6１56 ケ 月）を経過していた。下肢の麻痺の程度についてはBr. ステージIIIが25名と最も多かった（表1）。

なお, 対象者には研究の趣旨と内容について十分に 説明し，同意を得た後研究を開始した。

表1 対象者の属性

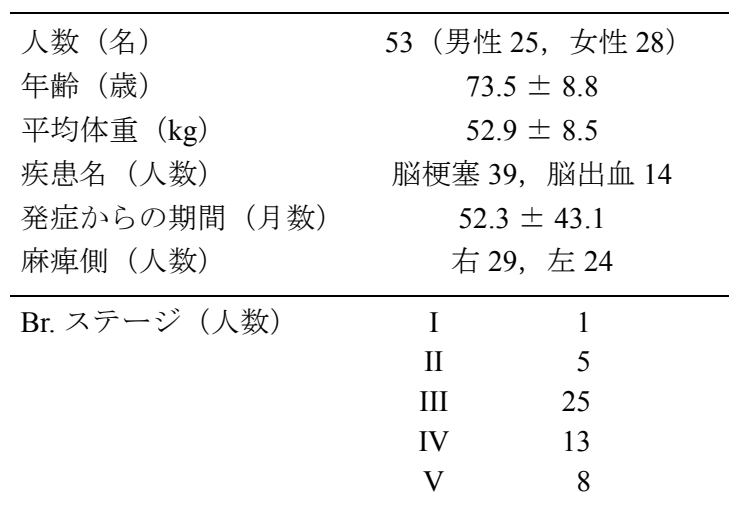

平均土標準偏差 


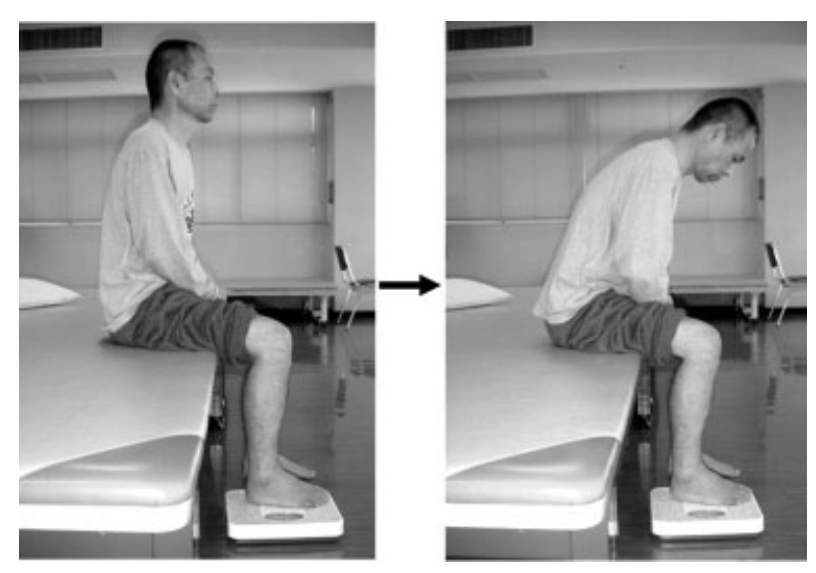

図1 下肢荷重力の測定

下肢で体重計を最大努力下で3秒押す，その際，臀部を治療 台から離さないように留意した。

\section{2. 方法}

測定姿位は, 治療台 (プラットホーム型 : 高さ45 cm) に端座位をとり，足底に体重計を置いた状態で治療台 端と膝窩部間を拳一個分空ける。測定開始の合図とと もに, 下肢で体重計を垂直方向に最大努力下で3秒間押 してもらった。その際, 体幹の矢状面および前額面で の動きは制限せず，体重計を押し易い姿勢をとらせた が，殿部を治療台から離さないように留意した（図1）。 測定は非麻痺側および麻痺側につき 2 回ずつ行い, その 最大值の合計を下肢荷重力（kg）とした。

本研究では, 下肢荷重力を左右の測定值の合計で評 価した。高齢者の体力評価を行う際には, 左右の測定 值の合計や平均值を指標とした研究が散見される18-20)。 前田ら ${ }^{18)}$ は, 歩行障害を有する高齢者を対象に, 歩行 可能な下肢筋力の推定を行っている。それによると， 歩行の可否の判別が行えたのは健側あるいは患側の一 方の筋力ではなく，両側の合計值であったと報告し， 高齢者における両側の測定值を体力評価の指標とする 重要性を報告している。著者らの先行研究15,21)におい ても, 座位での下肢荷重力測定は, 麻痺側や非麻痺側 それぞれを測定・評価するのではなく，両側を評価す ることの重要性を示している。これらの報告に基づき, 本研究では左右の測定值の合計を下肢荷重力の指標と した。なお下肢荷重力は，体重比百分率（\%）に換算 して分析した。

歩行能力は屋外歩行可能群, 屋内歩行可能群, 歩行 不能群の3群に分類した。屋外歩行可能群とは, 実際の 日常生活において屋外を介助なしで歩行している者と
し, 屋内歩行可能群とは, 屋外歩行には介助を要すが, 通所リハビリテーション施設内の歩行は介助なしで可 能な者とした。歩行不能群とは, 歩行不能あるいは施 設内の歩行に介助が必要な者とした。なお，歩行には 装具の装着と杖の使用を許可した。

立ち上がり能力は立ち上がり可能群，条件付き可能 群, 不可能群の3群に分類した。立ち上がり可能群とは, 治療台（プラットホーム型：高さ45 cm）での端座位か ら上肢を使用することなく立ち上がりが可能な者とし， 条件付き可能群とは, 上肢で治療台を押すことによっ て立ち上がりが可能となる者とした。不可能群とは, 立ち上がりが不能あるいは介助が必要な者とした。

立位保持能力は立位保持可能群, 条件付き可能群, 不可能群の3群に分類した。立位保持可能群とは, 上肢 の支持無しで10秒間の立位保持が可能な者とし, 条件 付き可能群とは，一本杖を持つことによって立位保持 が10秒間可能な者とした。不可能群とは, 一本杖を持っ ても10秒間の立位保持ができない者とした。

統計処理について歩行, 立ち上がり, 立位保持のそ れぞれにおける能力別の3群間の比較には, 一元配置分 散分析を用いて検討し, その後, Scheffeの多重比較検 定を行った。

なお，すべての統計解析にはStat View 5.0を用い，統 計的有意水準を $5 \%$ 未満とした。

\section{III. 結 果}

対象者の歩行能力は, 屋外歩行が可能な者が25名, 屋内歩行が可能な者が13名, 歩行不能の者が15名であつ た。それら3群間の下肢荷重力を比較すると, 群間に有 意差 $(\mathrm{p}<0.01)$ が認められ, 多重比較検定により屋外歩 行可能群および屋内歩行可能群の下肢荷重力は, 歩行 不能群のそれより有意 $(\mathrm{p}<0.01)$ に強かった。屋外歩行 可能群と屋内歩行可能群には有意差は認められなかっ た（表2）。

対象者の立ち上がり能力は, 立ち上がりが可能な者 が16名, 非麻痺側上肢で治療台を押すことにより立ち 上がりが可能となる者が 25 名, 立ち上がりが不可能な 者が12名であった。それら3群間の下肢荷重力を比較す ると, 群間に有意差 $(\mathrm{p}<0.01)$ が認められ, 多重比較検 定により立ち上がり可能群, 条件付き可能群, 不可能 群の順に有意差 $(\mathrm{p}<0.01)$ が認められた（表 2$) 。$

対象者の立位保持能力は, 立位保持が可能な者が 24 名，一本杖を持つことによって立位保持が可能な者が 17 名, 立位保持が不可能な者が12名であった。また, そ 
各動作能力別における下肢荷重力の比較

\begin{tabular}{|c|c|c|c|c|c|}
\hline \multirow{2}{*}{ 歩行能力 } & \multirow{2}{*}{$\begin{array}{c}\begin{array}{c}\text { 屋外歩行可能 : A } \\
\mathrm{n}=25\end{array} \\
64.3 \pm 15.4\end{array}$} & \multirow{2}{*}{$\begin{array}{c}\begin{array}{c}\text { 屋内歩行可能 : B } \\
\mathrm{n}=13\end{array} \\
59.7 \pm 11.4\end{array}$} & \multirow{2}{*}{$\begin{array}{c}\begin{array}{c}\text { 歩行不能 : C } \\
n=15\end{array} \\
42.4 \pm 11.8\end{array}$} & \multicolumn{2}{|c|}{$\mathrm{F}$ 值危険率多重比較 } \\
\hline & & & & $11.97 * *$ & $\mathrm{~A} \cdot \mathrm{B}>\mathrm{C}^{* *}$ \\
\hline & $\begin{array}{c}\text { 立ち上がり可能 : A } \\
n=16\end{array}$ & $\begin{array}{c}\text { 条件付き可能 : B } \\
n=25\end{array}$ & $\begin{array}{c}\text { 不可能 : C } \\
n=12\end{array}$ & $\mathrm{~F}$ 值 & 危険率多重比較 \\
\hline \multirow[t]{2}{*}{ 立ち上がり能力 } & $69.6 \pm 12.7$ & $56.5 \pm 14.0$ & $41.9 \pm 11.7$ & $14.5 * *$ & $\mathrm{~A}>\mathrm{B}>\mathrm{C}^{* *}$ \\
\hline & $\begin{array}{c}\text { 立位保持可能 : A } \\
n=24\end{array}$ & $\begin{array}{c}\text { 条件付き可能 : B } \\
n=17\end{array}$ & $\begin{array}{c}\text { 不可能 : C } \\
n=12\end{array}$ & $\mathrm{~F}$ 值 & 危険率多重比較 \\
\hline 立位保持能力 & $63.6 \pm 17.4$ & $57.2 \pm 11.0$ & $44.2 \pm 13.6$ & $6.53 * *$ & $\mathrm{~A} \cdot \mathrm{B}>\mathrm{C}^{*}$ \\
\hline
\end{tabular}

下肢荷重力は，体重比百分率（\%) で表す.

平均土標準偏差. 反復測定分散分析, 多重比較検定; Scheff's $\mathrm{F}{ }^{*} \mathrm{p}<0.05 * * \mathrm{p}: 0.01$

れら3群間の下肢荷重力を比較すると，群間に有意差 $(\mathrm{p}<0.01)$ が認められ, 多重比較検定により立位保持可 能群および条件付き可能群の下肢荷重力は，立位保持 不可能群のそれより有意 $(\mathrm{p}<0.05)$ に強かった。立位保 持可能群と条件付き可能群には有意差は認められなかっ た（表2）。

\section{IV. 考 察}

本研究は, 片麻痺患者の歩行, 立位保持ならびに立 ち上がり動作能力と下肢荷重力との関係を調査し，下 肢荷重力測定法の有用性について検討することを目的 とした。その結果, 下肢荷重力はそれぞれの動作の能 力差に対応して変動することが明らかとなった。

著者らは, 先行研究16)において片麻痺患者の歩行能 力と有意な相関関係があることを報告した。本研究結 果においても, 屋外歩行および屋内歩行可能な対象者 群に対して歩行不能群の下肢荷重力は有意に低い值を 示した。さらに，立位保持と立ち上がり動作能力に関 しても, 動作可能群および条件付き可能群に比較して, 不可能群の下肢荷重力は有意に小さかった。これらの 結果は, 下肢荷重力測定による評価が歩行, 立位保持, あるいは立ち上がり動作の可否判定の指標となり得る ことを示唆した。

さらに, 立ち上がり動作可能群に関しては, 動作レ ベルの違い（非麻痺側上肢補助なし vs 非麻痺側上肢補 助あり）で下肢荷重力に有意な差が認められた。この
結果は，下肢荷重力測定が片麻痺患者の立ち上がり動 作能力のレベル判定に利用できる可能性を示唆してい る。

しかしながら，歩行および立位保持可能群において は，動作レベルの違い（歩行では屋外 vs 屋内，立位保 持では上肢の支持なし vs 一本杖使用）で下肢荷重力に 有意差は認められなかった。これらの結果は，下肢荷 重力測定による評価が歩行や立位保持動作において, 動作の可否判定の指標としては利用できるが，レベル 判定など詳細な機能評価には適していない限界を示し ている。

このように，下肢荷重力と動作能力レベルとの関係 が，動作の違いによって異なる理由について，本研究 では明らかにできないが，つぎのことが推察される。 それは，各動作で使用される身体機能的要素の違いで ある。先行研究17)において, 下肢荷重力は下肢筋力お よび座位バランス能力と密接な関係があることが報告 されている。立ち上がり動作はこれらの身体機能的要 素が重要な役割を果たしているため, 本研究で得られ た下肢荷重力測定值の結果が立ち上がり動作のレベル の違いに反映されたものと推察される。

一方，歩行や立位保持能力は下肢筋力だけでなく， 立位バランス能力が強く関与している。藤澤ら ${ }^{22}$ は, 片 麻痺患者の歩行能力を高めるためには, 麻痺側片脚立 位保持能力を高める必要があることを報告し, 鈴木ら 23) は, 片麻痺患者の歩行能力の生体力学的決定因子は, 立位バランスと膝伸展筋力であると述べている。これ 
らのことから, 下肢荷重力測定值と歩行や立位保持能 カレベルとの間の適合性が低かったものと推察した。

本研究における下肢荷重力測定法は, 坐位で測定が 可能なため, 立位や歩行が困難, あるいは治療上立位 動作が許可されていない片麻痺患者の予後予測に使用 できるという利点が考えられる。ただし，立位保持や 歩行能力に関して詳細に検討するのであれば, 立位バ ランスや筇力評価など, その他の機能評価をあわせて 行う必要性が示唆された。今後は, 下肢荷重力を高め ることが片麻痺患者の立位動作能力の向上につながる のか否か, 下肢荷重力を効果的に高めるための方法な ど, 縦断的研究や介入研究によって検証することが課 題である。

\section{引用文献}

1) 上田 敏 : 目で見るリハビリテーション医学, 第2版. 東京 大学出版会, 東京, 1999, pp44-47.

2) 岩谷 力, 飛松好子: 障害と活動の測定・評価ハンドブック 一機能からQOLまで. 南江堂, 東京, 2005, pp177-180.

3) 道免和久 : 脳卒中片麻痖患者の機能評価法Stroke Impairment Assessment Set（SIAS）の信頼性および妥当性の検討（1）麻痺側運動機能, 筇緊張, 腱反射, 健側機能. リ八医学, 1995, 32(2) : 113-122.

4) 道免和久, 才藤栄一, 園田茂 $\cdot$ 他: 脳卒中機能障害評価 セットStroke Impairment Assessment Set（SIAS）（2）麻痺側運 動機能評価項目の信頼性と妥当性の検討. リ八医学, 1993, 30(2) : 310-314.

5) 菅原憲一, 内田成男, 石原 勉 - 他 : 片麻痺患者の歩行能力 と麻瘏側機能との関係. 理学療法学, 1993, 20(5) : 289-293.

6) 杉本 諭, 網本 和: 脳血管障害患者の歩行能力に及ぼす非 麻痺側筋力と坐位能力の影響. 理学療法学, 2000, 27(1) : 4-8.

7) 阿部 長, 丸山 泉, 原 直哉: 脳卒中片麻痺患者における 下肢筋出力特性が歩行速度に及ぼす影響. 理学療法学, 1994, 21(7) : 411-415.

8) 佐直信彦, 中村隆一: 脳卒中片麻痺患者の立位バランスの決 定因子. リ八医学, 1993, 30(6) : 399-403.

9) 鈴木堅二, 中村隆一, 山田嘉明 - 他 : 脳卒中片麻痺患者の最 大歩行速度と立位バランス. リ八医学, 1992, 29(7) : 577-580.
10) 神戸晃男, 山田俊昭, 西村誠次・他 : 歩行速度の違いによる 筋活動の差の筋電図学的研究. PTジャーナル, 1993, 27(10) : 721-725.

11) 本田亜紀子, 田原弘幸, 山本秀正 - 他 : 脳卒中片麻痺患者に おける立位時患側体重負荷率と歩行・バランス能力の関連. 長崎大学医療技術短期大学部紀要, 1992, 5 : 187-191.

12) 浅野 賢, 熊井初穂, 新田富士子 : 脳卒中片麻痺におけるブ リッジ動作の定量的評価. 理学療法学, 1991, 18(2) : 137-140.

13) 山崎裕司, 大森圭貢, 青木詩子・他: 市販体重計を用いた脚 伸展筋力の測定. PTジャーナル，1998，32(7) : 542-543.

14) 大森圭貢, 山崎裕司, 横山仁志 $\cdot$ 他 : 高齢入院患者の脚伸展 筋力と歩行自立度・歩行速度の関連. 理学療法, 1999, 16(11): 913-917.

15) 村田 伸, 宮崎正光 : 障害高齢者の下肢機能評価法一市販体 重計を用いた下肢支持力の測定. 理学療法科学, 2005, 20(2): 111-114.

16) 村田 伸, 大田尾浩, 有馬幸史・他: 脳卒中片麻痺者におけ る市販体重計を用いた下肢荷重力評価の検討. PTジャーナ ル, 2006, 39(12) : 1101-1105.

17) 村田 伸, 甲斐義浩, 村田 潤 : 下肢荷重力と下肢筋力およ び坐位保持能力との関係. 理学療法科学, 2006, 21(2) : 169173.

18) 前田哲男, 森本典夫, 黒瀬富義・他：高齢歩行障害患者が歩 行可能な下肢筋力の推定. 運動 - 物理療法, 2000, 11(4) : 293-298.

19) 池添冬芽, 浅川康吉, 羽崎 完・他：高齢者における起居移 動動作自立に必要な膝伸展筋力について. 理学療法科学, 1997, 12(4) : 179-181.

20) 西島智子, 小山理惠子, 内藤郁奈・他 : 高齢患者における等 尺性膝伸展筋力と歩行能力との関係. 理学療法科学, 2004, 19(2) : 95-99.

21) 大田尾浩, 村田 伸, 有馬幸史・他 : 脳卒中片麻痺者におけ る立ち上がり能力と座位での下肢荷重力との関連. 理学療法 科学, 2007, 22(2) : 293-296.

22) 藤澤宏幸, 武田涼子, 前田里美・他 : 脳卒中片麻瘏患者にお けるFunctional Reach Test と片脚立位保持時間の測定の意義 一歩行能力との関係に着目して. 理学療法学, 2005, 32(7) : 416-422.

23) 鈴木堅二, 中村隆一, 山田嘉明・他 : 脳卒中片麻痺患者の最 大歩行速度と立位バランス。リ八医学, 1992, 29(7) : 577-580. 